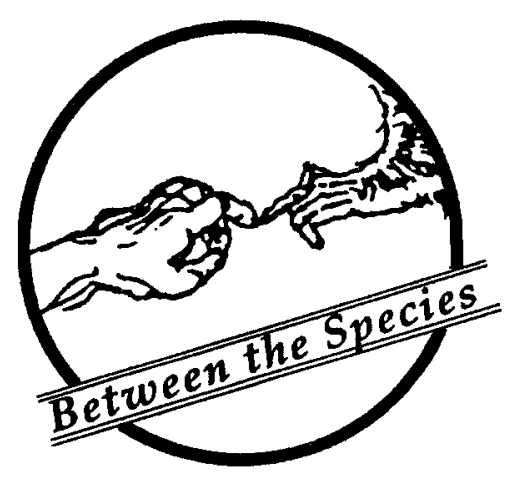

\title{
SERMON: "CHRISTIANS AND COMPANION ANIMALS"
}

\author{
Rev. Dr. Marc A. Wessels \\ International Network for Religion and Animals
}

\section{"For in him all the fulness of God was pleased to dwell, and through him to reconcile to himself all things..." \\ - Colossians 1.19-20}

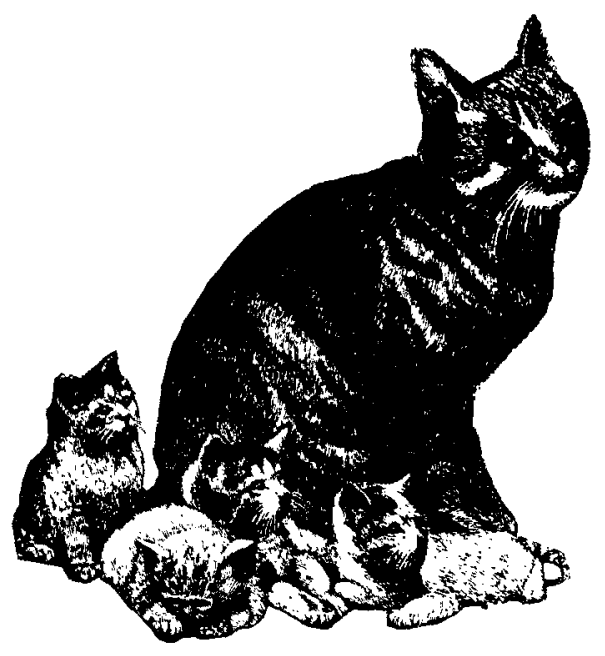

We celebrate on this special day, proclaiming the good news to both human and non-humans

that Jesus Christ has risen.

The God who took on human form

is the person whom God raised from the dead.

It is this man, the "New Adam,"

which brings the promise of new life to all of God's creatures.

As we read in the epistle to the Colossians, God was pleased to take on physical form, to reside in the physical world on our planet earth,

in order that God might bridge the gulf which existed between Himself and all things because of human $\sin$ :

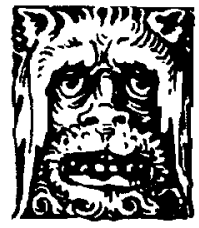


Our celebration of World-wide Week of Prayer for Animals

underscores our personal and faith community's commitment

to re-evaluating and renewing our relationship

with God's creatures.

The challenge exists for people such as ourselves

to demonstrate that the religious community is determined

to be a part of the movement which responds positively

with moral force to the cry, the "groaning and travail" of the animals.

Today, we need to remember and recognize our attachment to the natural environment by the means with which most of us have some common, everyday experience.

Almost all of us have had one or more animals in the past,

and a good number of you are now presently fortunate

to have the pleasure of companion animals in your home.

\section{"...when we elevate}

companion animals to the

status of persons; when we

empathize with them and

acknowledge their

resemblance to ourselves, it

eventually becomes clear

that the notion of human

ascendancy is a phantom: a

dangerous, egotistical myth

that currently threatens our

survival."
What we choose to stress throughout this week

is that our attitudes and understandings towards these animals

is crucial and can,

indeed must

if we are serious about our faith,

be formed by a Christian conscience of compassion.

Christians, through scripture and tradition,

have a recognition of the innate goodness of the animal kingdom.

As a part of God's creative activity,

on the fifth day, before forming men and women, according to the book of Genesis,

God made the animals.

Later, we read in the scriptures that Adam,

representing all humanity,

had the distinctive responsibility of naming the animals

and was in relationship with them.

To have the power to name is significant.

When one chooses a name for a dog or a cat,

one is selecting a title by which that particular animal will be known.

Names given to companion animals

are usually as indicative of the people naming them as

they are of the animals being named.

The Psalmists were certainly aware of the animals which God had made.

They recognized their beauty and individual abilities.

They also recognized that all animals ultimately belonged not to them

but to God who knows them,

As we read in Psalm 50:

"...Every beast of the forest is mine, the cattle on a thousand hills.

I know all the birds of the air,

and all that moves in the field is mine.

The people who wrote the scriptures saw that they were,

like Adam,

to be proper stewards of the animals.

Wisdom about care for their animals was counselled. 
In the books of the Law there are many indications

of the proper relationships which should exist between man and animals,

for example in the book of Proverbs it says:

"The righteous man has regard for the life of his beast."

As Christians, we have an obligation,

a divine commission to care for the animal kingdom.

We must be concerned about and care for animals,

just as we need to be concerned about other humans.

Just as we are attentive about the rights of people, so must we move from our attitudes and thinking from an anthropocentric framework,

that is,

from viewing the world and all that is in it

only in terms of human beings at the centre.

Our duty to the animal creation has not, unfortunately,

always been correctly fulfilled.

We need keep in mind that God created the animals,

but, like Adam, we have responsibility for them.

And we,

through our lives and lifestyles determine their fate.

As one writer has put it,

"On the Fifth Day,

Creation of Beings began

Their fate determined by For either good or ill

And so it continues still."

One practical place where each of us can begin to determine

that the fate of animals will be for good instead of ill

is in our homes, starting with our companion animals.

I am thinking especially about these animals which we used to call pet

but now, recognizing the limits of that word,

sensitively choose the more appropriate term companion animals.

Dogs and cats are the most widely accepted animals in homes today in the Western world.

As British author James Serpell

noted in his book, In the Company of Animals,

"...when we elevate companion animals to the status of persons;

when we empathize with them

and acknowledge their resemblance to ourselves,

it eventually becomes clear that the notion of human ascendancy

is a phantom: a dangerous, egotistical myth that currently threatens our survival."

These animals,

when we see them as individual persons,

recognize their unique abilities,

and enjoy their company and affection are signs of God's nature.

The faithfulness of a dog can easily represent

the faithfulness of a God which never loses respect or love

for his people despite the horrible things they do against him and others.

Likewise, the independence of a cat can be an illustration

of how elusive that loving God may sometimes appear,

here at the moment in close proximity,

then seemingly gone in a flash of an eye.

Our companion animals can make us more aware of our biological affinities with animals and the natural world,

a world which God has made and placed us in.

Our companion animals help us,

when we look,

to see God more clearly.

We rightly grieve, when we lose our companions, yet we find assurance in the knowledge that they ultimately belong to God and He revels in them.

As Christians, we rightly honour God, When we love not only man, but also the beast.

An excellent example of such a balance of love is found in Saint Theonas,

a man of letters from the Fourth Century. 
According to tradition,

St. Theonas often had the sick swarm around his home.

He used to appear at the window and extend his hand,

give a blessing, heal the crowd, and withdraw without a word.

At night he crossed the threshold of his dwelling, in order to give the beasts of God,

the animals of the desert,

the clear water of his fountain.

Apparently his shelter was always surrounded

by stout wild buffaloes, light-footed goats, and wild asses

which seemed to form a guard of honour around the friend of God and also of nature.
Theonas obviously gave and received from his companion animals.

His understanding of loving God included both the healing of man and beast.

Perhaps, on this Sabbath, as we consider his ability, and our experience of the animals around us, we might draw ourselves closer to God, giving thanks to the Creator for granting us companion animals.

May we always wisely honour them, and by so doing,

honor their Lord, which is also our own. Amen.

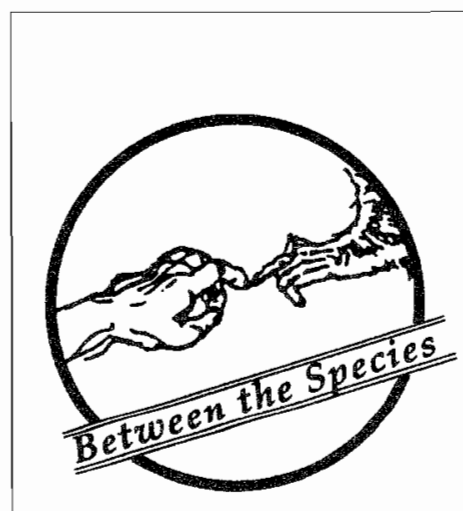

Now 60 pages! Not only the best writing on ethics and animals, but fiction, poetry, and autobiography by leading animal liberationists too! "Between the Species is a must for anyone who feels we have to toss away our old conceptions about animals as ... not deserving ethical treatment, and find a way of relating to them as, perhaps, peers." - Jim Swan (Shaman's Drum)

\section{Contributing Editors include Peter Singer, Michael Fox, Bernard Rollin and Tom Regan.}

$\square$ Enclosed is $\$ 15.00$ for a one-year subscription to Between the Species.

$\square$ Enclosed is $\$ 3.00$ for a sample back issue of Between the Species.

Name:

Street:

City: State: Zip Code:

\section{San Francisco Bay Institute \\ P.O. Box 254 \\ Berkeley, California 94701}

